\title{
A Study on work out costs and returns and examine resource use efficiency in Mustard production on sample farms
}

\author{
Praveen Kumar Sahu*, Gyan Prakash Singh and Rajeev Singh \\ Department of Agricultural Economics, Narendra Deva University of Agriculture and \\ Technology Kumarganj, Faizabad (U.P.) 224229, India \\ *Corresponding author
}

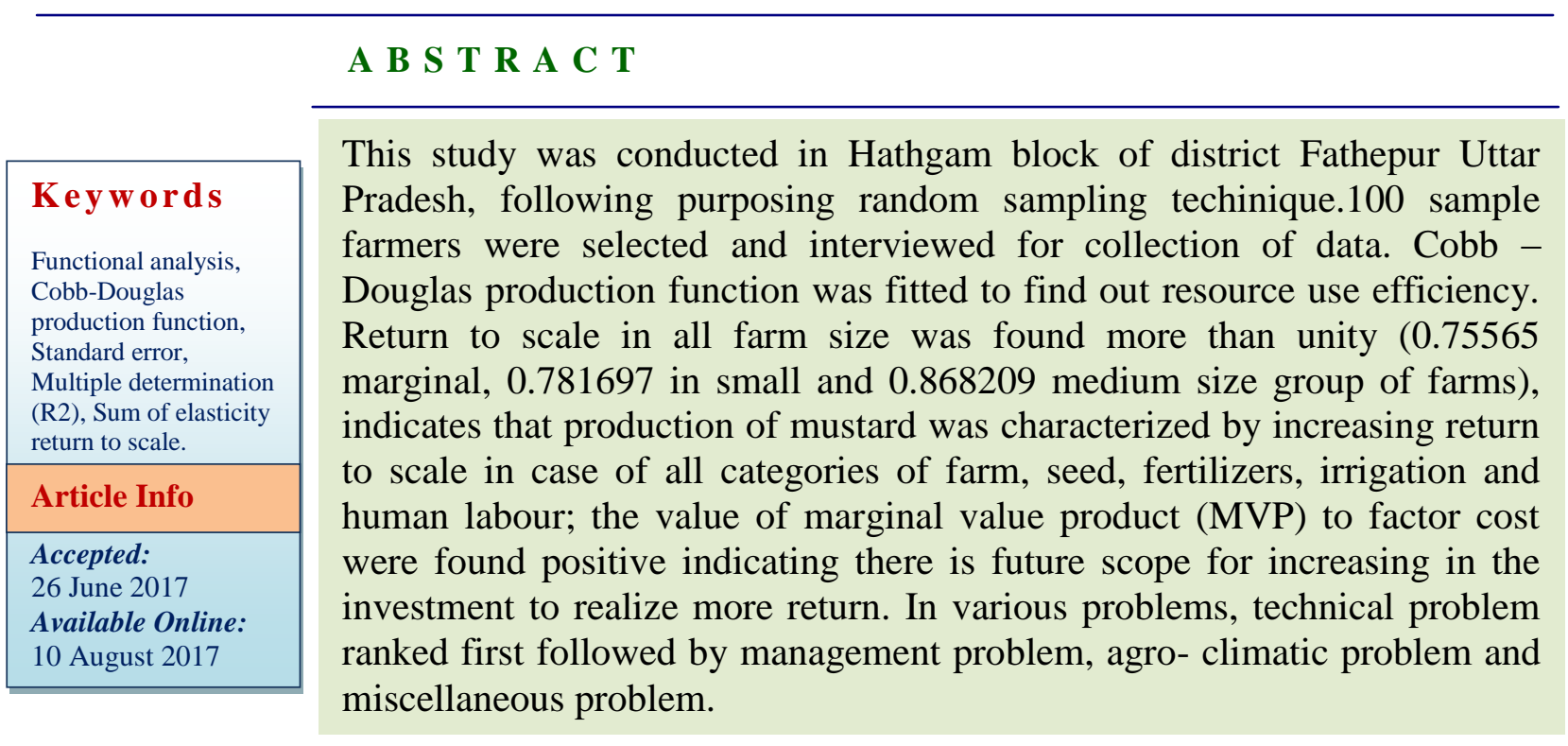

\section{Introduction}

India is one of the four major players in the vegetable oil scenario of the world, being one of the important oilseed growers, importer and exporter. Besides, India is the second largest producer of rice and cotton, which would yield valuable rice bran oil and cotton seed oil. Among the nine oilseed crops grown in the country, seven are of edible oils (soybean, groundnut, rapeseed-mustard, sunflower, sesame, safflower and Niger) and two are of non-edible oils (castor and linseed).

The vegetable oil scenario is very complex and is generally influenced by market forces, conflicting interests, vagaries of weather, technology and various biotic and abiotic problems. Favourable agro ecological conditions in the country have supported commercial cultivation of seven annual edible and two non-edible oilseed crops besides a number of a number of minor oilseeds of horticultural and forest origin including in particular coconut and oil palm.

There has been a continuous improvement in the production and productivity of oilseeds in India in the last 55 years, despite wide fluctuation from year to year in response mainly to climate condition. There has been 
more than five times increase in oilseeds production during the period 1950 to 2005 and 2.5 times increases since 1986 under predominantly rainfed agro-ecological conditions. Overall during 1986-2004, the production of oilseeds grew at the rate of 2.84 per cent per annum along with productivity growth of 1.95 per cent and the area growth of 0.84 per cent.

The agriculture sector plays a very important role in India's social security and overall economic welfare. Oilseeds crops are the second most important determinant of agricultural economy, next only to cereals. India is the largest producer of oilseeds in the world and accounts for about 14 per cent of the global oilseeds area, $7 \%$ of the total vegetable oil production, and $10 \%$ of the total edible oils consumption. In India, oilseeds accounts for $3 \%$ to the Growth of National Products and $10 \%$ to the total value of all agricultural products, and employs 14 and 1 million people respectively in oilseed cultivation and processing. In 2012-13, the total oilseed cultivated area, the total oilseed seed production and the total edible oil production, respectively, were 27 million ha, 29 million matric tones (mmt) and $7.45 \mathrm{mmt}$. Presently, India's annual edible oil consumption is about $17.5 \mathrm{mmt}$, which in the last decade has increased steadily at a compounded annual growth rate of $4.6 \%$.

The growth in per capita consumption is attributable to both rising income levels and living standards. However, the current per capita consumption of $14.3 \mathrm{~kg} /$ year in 2012 13 in India is considerably lower than the global average of $24 \mathrm{~kg}$ /year. In 2012-13, the major edible oils consumed in the country are palm oil, soybean oil and mustard oil, with their respective shares of $46 \%, 16 \%$ and $12 \%$. Given the taste preferences and the high price consciousness of the consumers, it is expected that these three oils will continue to account for the bulk of the edible oil consumption in India (FAO Stat).

Unfortunately, the increase in the domestic oilseeds production has not been able to keep pace with the increasing demand. In fact, according to figures available, the production of oilseeds grew marginally by close to $2 \%$ annually from 2003-04 to 2012-13 as against compounded annual growth rate of $4.6 \%$ in demand. Therefore, the gap in demand and supply is being bridged by importing about 9 mmt of edible oil at a cost of about Rs. 65000 crores. The major factors responsible for low and unstable yields are cultivation of most oilseeds crop in rain fed and high risk environments, farmers shifting from oil crops to cultivation of other high-priced non-oil commercial crops. Rapeseed-mustard, groundnut and sunflower, respectively, have oil recovery ratios of $45 \%, 40 \%$ and $30 \%$, compared to only 11.5 and $17 \%$ of cotton seed and soybean. The importance and potential of rapeseed-mustard crop is well known as it is the only crop that can meet the challenge of demand and supply gap of edible oil in India. It is world's third most important source of edible oil after soybean and palm. Each and every part of the plant is of importance in the human livelihood. It is also being utilized for flavoring, medicines and as preservatives, and several value added products since time immemorial.

In India, the cultivation of oilseeds is in high risk regions where there are uncertain returns on investments. They are mostly grown in dryland areas which are characterized with scanty and uneven rainfall, poor soil health, etc. The oilseed economy of the country faces a huge of challenges on technological, institutional and policy fronts. The capability in designing and implementing innovative approaches to adequately address each of these challenges will determine the future of the oilseed economy of India. Oilseed 
cultivation in India is predominantly dependent on rainfall and this leads to a higher magnitude of instability in production of oilseeds. Often, the marginal lands are earmarked for cultivation of oilseed crops. Such inherent disadvantages ensure that a productive field is not provided to the oilseed crops even when they are being compared increasingly with their competing crops in terms of production, productivity and profitability.

On an average, the country produces about 6 mmt of rapeseed-mustard seed annually, and $80 \%$ of this is marketed by the small-scale sector in loose form, with only $20 \%$ sold by the organized sector. A major portion of seeds enters the regulated Mandis (organized markets for selling agricultural products) and is purchased by oilseed crushers for oil extraction and production of oil meal. Rapeseed- mustard is the largest consumed oil accounting for about $26 \%$ of the total edible oil produced domestically. Major consuming states of rapeseed-mustard oil in India are: Gujarat, Maharashtra, Rajasthan and Madhya Pradesh accounting 9\%, Delhi, Punjab, J\&K, Himachal Pradesh and UP accounting 25\% and East West Bengal, Orissa, Bihar, Assam, Chhattisgarh, Jharkhand accounting about $30 \%$. The oil content in rapeseed-mustard typically varies between 36 and $45 \%$. Once the oil is extracted, the remaining part cake is an important source of cattle and poultry feed. Annually, India exports about $7 \mathrm{mmt}$ of seed meals adding about Rs 11000 crores to the national economy. After soybean, rapeseedmustard meal accounts for about $37.5 \%$ of the total seed meal exported from the country. In India, although the personal income derived from agriculture is exempted from income tax, central and state governments generate revenues from oilseed sector by means of several taxes including intra and inter-state sales tax by sellers, about $4 \%$ of value added tax in many states, and $8 \%$ excise duty on branded and packed edible oils by oilseeds crushers.

In India mustard is mainly grown in North West part of India, Rajasthan, and U. P. are the major mustard producing state in the country. Rajasthan is the largest mustard producer in the country with a contribution of (54\%) to the country's total mustard production followed by Punjab and Haryana which simultaneously contributes (14\%). In India area under mustard was 6051 million hectares and its production was 7.67 million tones with productivity $1179 \mathrm{~kg} / \mathrm{ha}$ in 2010 11 (Directorate of Economics and statistics, New Delhi). While area, production and productivity in U.P. were 0.61 million hectare, 0.68 million tonnes and $1113 \mathrm{Kg} / \mathrm{ha}$ respectively. (2009-10 Directorate of Economics and statistics, New Delhi). During the same period area, production and productivity of Mustard in Fatehpur District was 25221 hectare, $14164 \mathrm{mt}$. and $562 \mathrm{~kg} / \mathrm{ha}$, respectively (2013-14www.spatrika.nic.in).

Area of oilseed in India during 2011-12and 2012-13 were respectively, 263.08, 264.84 million ha, production of oilseeds during said period were 29.80 and 30.94 million tonnes, respectively and the productivity in related period was 1133 and $1168 \mathrm{~kg} / \mathrm{ha}$. (FAO, 2011-12 and 2012-13). The production of oilseeds, though it has increased in recent years from 184.40 lakh tonnes in 2000-01 to 297.99 lakh tonnes in 2011-12, has not kept pace with the demand for edible oils in India. In World's $8.0 \%$ area covered under oilseed cultivation which accounted to 26.27 M./ ha, offering an average yield of $1100 \mathrm{~kg} / \mathrm{ha}$. $(F A O, 2012)$. Oilseeds are gaining great importance and position in the farming system in the country owing to increase in demand for edible oils and oil seed products. Rapeseed mustard is the second most important oil seed crop in India after soybean. Rapeseed mustard are the major rabi oilseed 
crop of India. It occupy a prominent place being next in importance to groundnut; both in area and production; meeting the fat requirement of about 50 per cent population in the states of Uttar Pradesh, Punjab, Rajasthan, Madhya Pradesh, Bihar, Orissa, West Bengal and Assam.

India is one of the largest producer of rapeseed and mustard in the world. India's contribution in the world's rapeseed mustard production is the highest of any country. The production of rapeseed and mustard in India accounts for about 18 per cent of the total oilseed production of the country. The seeds and oil are used as condiment in the preparation of pickles and for flavoring curries and vegetables. The oil is utilized for human consumption through-out northern India in cooking and frying purpose. It is also used in the preparation of hair oil and medicines. It is used in soap making, in mixtures with mineral oils for lubrication. Rapeseed oil is used in the manufacture of greases. The oil cake is used as a cattle feed and manure. Green stems and leaves are a good source of green fodder for cattle. The leaves of young plants are used as green vegetables as they supply enough sulphur and mineral in the diet. In the tanning industry, mustered oil is used for softening leather.

The importance of oilseeds crop is well recognized with regard of national economy, generation of income and employment to the rural people in its various uses, as well as a major source of fat for balance human diet. It is also accepted as low input and high output crop among various crops grown on the farmer's field.

\section{Materials and Methods}

The Sampling technique was used for following the selection of district, block, villages and respondents. Selection of
Fatehpur district was selected purposively to avoid the operational inconvenience of the investigator. Selection of Block out of 13 blocks of selected district, one block namely Hathgam was selected randomly. Selected of villages a list of all the villages falling under selected block was prepared and arranged in ascending order according to area covered by mustard crop and 5 villages were selected randomly from the list. Selection of respondents a separate list of mustard growers of selected five villages was prepared along with their size of holdings. Thus the farm holding categorized into three size groups i.e. (1) Marginal: Below 1.0 hectare, (2) Small: 1.0 to below 2.0 ha and (3) Medium: 2.0 to 4.0 ha from this list a sample of 100 respondents were selected following the proportionate random sampling technique.

\section{Method and Techniques of Analysis (Analytical tools used)}

Both tabular and functional analysis were used in the study. Percentage and weighted average in tabular analysis and Cobb-Douglas production function for functional analysis were applied to find-out the result and interpretation of data.

\section{Weighted Average}

The simplest and important measures of average which have been used into statistical analysis were the weighted average.

To estimate the weighted average following formula was used:

$$
\text { W.A. }=\frac{\sum \mathrm{W}_{\mathrm{i}} \mathrm{X}_{\mathrm{i}}}{\sum \mathrm{W}_{\mathrm{i}}}
$$

Where,

W.A. = Weighted average 
$\mathrm{X}_{\mathrm{i}}=$ variable

$\mathrm{W}_{\mathrm{i}}=$ Weights of $\mathrm{X}_{\mathrm{i}}$

\section{Functional analysis}

To study the effect of various independent variables on the output, various form of production function have been dealt, and Cobb-Douglas function was found best fit, therefore it was used for measuring resource use efficiency.

\section{Mathematical form of Cobb-Douglas function}

$\mathrm{Y}=\mathrm{aX}_{1}{ }^{\mathrm{b} 1} \cdot \mathrm{X}_{2}{ }^{\mathrm{b} 2} \cdot \mathrm{X}_{3}{ }^{\mathrm{b} 3} \cdot \mathrm{X}_{4}{ }^{\mathrm{b} 4} \cdot \mathrm{e}_{\mathrm{u}}$

Where,

$\mathrm{Y}=$ per hectare output (Rs.)

$\mathrm{a}=$ constant

$\mathrm{X}_{1}=$ Cost of seed material (Rs./ha)

$\mathrm{X}_{2}=$ Total human labour (Rs./ha)

X3 = Manure \& fertilizer (Rs./ha)

$\mathrm{X}_{4}=$ Irrigation charges $(\mathrm{Rs} . / \mathrm{ha})$

$\mathrm{e}_{\mathrm{u}}=$ Error term

$b_{1}, b_{2}, b_{3}$ and $b_{4}$ are production elasticities of the respective input variables.

\section{Cobb-Douglas Production Function in Log} Form

$\log \mathrm{Y}=\log \mathrm{a}+\mathrm{b}_{1} \log \mathrm{X}_{1}+\mathrm{b}_{2} \log \mathrm{X}_{2}+\mathrm{b}_{3}$

$\log X_{3}+b_{4} \log X_{4}+u \log _{e}$

This formula was used for estimating the parameters of the function based on sample data.

\section{Marginal value Productivity}

The marginal value product of input were estimated by following formula-
$(M V P) X_{j}=b_{j} \frac{\bar{Y}}{\bar{X}_{j}}$

Where,

$b_{j}=$ Production elasticity with respect to $X_{j}$

$\bar{Y}=$ Geometric mean of the dependent variable $\mathrm{Y}$

$\bar{X}_{j}=$ Geometric mean value of $X_{j}$

$\mathrm{MVP}=$ Marginal value product of $\mathrm{j}^{\text {th }}$ input

\section{Test of significance}

Having estimated the elasticity coefficient, it is desirable to ascertain the reliability of these estimates. The most commonly used " $t$ " test was applied to know, whether " $b_{j}$ " is statistically significant or not at some specified probability level, following formula was used to calculate the " $\mathrm{t}$ " value.

"t $\mathrm{t}$ cal $=\mathrm{bj}_{\mathrm{j}} / \mathrm{SE}$ of $\mathrm{bj}_{\mathrm{j}}$

If calculated " $t$ " value is greater than the table value of " $t$ " at specific probability level and "n-k-1" degree of freedom, $b_{j}$ is said to be statistically and significantly different from zero ( $\mathrm{K}$-is number of independent factors and $\mathrm{n}$ is sample size).

F- Test was used to test the significance of the regression as a whole.

$$
\mathbf{F}=\frac{\operatorname{SSR} / \mathbf{K}}{\frac{\Sigma \mathbf{e}^{2}}{\mathbf{n}}-\mathbf{k}-1}
$$

Where,

$\mathrm{SSR}=$ Sum of square due to regression.

$\sum \mathrm{e}^{2}=$ Sum of squares of error term.

MVP of $\mathrm{J}^{\text {th }}$ input facter was tested by using formula. 
$\mathrm{t}=\mathrm{MVPj} / \mathrm{SE}$ of $\mathrm{MVP} j$

S.E. of $\mathrm{MVP}_{\mathrm{j}}=(\mathrm{X} / \mathrm{Y})$ Standard error of $\mathrm{b}_{\mathrm{j}}$.

\section{Results and Discussion}

It may be concluded that per hectare costs of cultivation of mustard increases with an increase in farm size.

On overall average, cost of cultivation per hectare of mustard came to Rs 30448.01. The net income, family labour income, farm investment income, and farm business income were found Rs. 13847.75, Rs 22669.76, Rs 24814.09 and Rs. 29661.67, respectively from mustard crop.

It is concluded from the results that various income measures were found in negative relation with size of holding.

Due to some unrecorded reasons cost per hectare increased with holding size but sample farmers of all three categories could received the equal yield. Which reversed the relationship of costs and income with size of holdings.

The Table revealed that, on an average cost $A_{1} / A_{2}$, cost $B_{1}$, cost $B_{2}$, cost $C_{1}$, cost $C_{2}$ and cost C3 came to Rs.14333.06, Rs.14824.97, Rs. 21324.97, Rs. 21180.01, 27680.01 and Rs. 30448.01, respectively.

On overall average, gross income was recorded Rs. 43994.73 and net income came to Rs.13847.75. On marginal farms, gross income was highest, which was recorded Rs.44173.71, followed by small farms Rs. 43861.68 and lowest on medium farms i.e. Rs. 43626.88, respectively.

The net income was highest on marginal farms Rs. (14074.33), followed by small farms Rs.(13637.95) and lowest medium farms Rs. (13501.04).On overall average family labour income, farm investment income and farm business income were observed to Rs. 22669.76, Rs. 24814.09 and Rs. 29661.67, respectively. Family labour income was highest on marginal farms followed by small and medium farms $\&$ farm investment income was highest on marginal farms followed by small and medium farms and farm business income was highest on marginal farms followed by small farms and medium farms.

On an average, cost of production per quintal was estimated to Rs. 2302.65 which was maximum on medium farms i.e. 2479.50 fallowed by small and marginal size of farms i.e. Rs. 2291.38 and Rs. 2268.22, respectively.

On an average input output ratio the basis costs $A_{1} / A_{2}, B_{1}, C_{1}, C_{2}$ and $C_{3}$ were recorded $1: 3.06,1: 2.96,1: 2.06,1: 2.07,1: 1.58$ and $1: 1.44$, respectively. On the basis of $\cos t \mathrm{C}_{3}$, the output: input ratio was highest on marginal farms i.e. 1:1.46 followed by small and medium size group of farms i.e. 1:1.45 and $1: 1.34$, respectively. It may be concluded from above discussion that marginal farmers were more conscious about economic cultivation of mustard, than the small and medium farmers. Which results in positive association of cost of cultivation and inverse relationship of income measures with size of holding on sample farms.

Cobb-Douglas production function was fitted to find out resource use efficiency in mustard crop. Per hectare gross income is taken as dependent variable and input costs of seed, manure \& fertilizers, irrigation and human labour was four independent input factors for mustard crop. The test of significance was examined by " $t$ " test for testing various input factors and " $F$ " test was applied for testing the regression as a whole. 
Table.1 Per hectare costs of different inputs used in Mustard production (Rs.)

\begin{tabular}{|c|c|c|c|c|c|}
\hline \multirow{2}{*}{$\begin{array}{l}\text { S. } \\
\text { No. }\end{array}$} & \multirow[t]{2}{*}{ Particulars } & \multicolumn{4}{|c|}{ Size group of farms } \\
\hline & & Marginal & Small & Medium & Overall average \\
\hline 1. & Human Labour & $\begin{array}{c}8808.18 \\
(29.26)\end{array}$ & $\begin{array}{c}8241.11 \\
(27.27)\end{array}$ & $\begin{array}{c}8870.95 \\
(27.25)\end{array}$ & $\begin{array}{c}8613.84 \\
(28.29)\end{array}$ \\
\hline a. & Family Labour & $\begin{array}{l}8129.38 \\
(27.01)\end{array}$ & $\begin{array}{c}4678.50 \\
(15.79)\end{array}$ & $\begin{array}{c}3736.55 \\
(11.48)\end{array}$ & $\begin{array}{l}6355.04 \\
(20.87)\end{array}$ \\
\hline b. & Hired Labour & $\begin{array}{l}678.80 \\
(2.26)\end{array}$ & $\begin{array}{c}3562.61 \\
(11.79)\end{array}$ & $\begin{array}{c}5134.40 \\
(15.77)\end{array}$ & $\begin{array}{c}2258.80 \\
(7.42)\end{array}$ \\
\hline 2. & Bullock labour & $\begin{array}{c}1019.74 \\
(3.39)\end{array}$ & $\begin{array}{c}0.00 \\
(0.00)\end{array}$ & $\begin{array}{c}0.00 \\
(0.00)\end{array}$ & $\begin{array}{l}529.91 \\
(1.74)\end{array}$ \\
\hline 2. & Machinery Charges & $\begin{array}{c}2025.00 \\
(6.73)\end{array}$ & $\begin{array}{c}3481.30 \\
(11.52)\end{array}$ & $\begin{array}{c}3682.79 \\
(11.31)\end{array}$ & $\begin{array}{c}2749.50 \\
(9.03)\end{array}$ \\
\hline 3. & Seed & $\begin{array}{l}712.05 \\
(2.37)\end{array}$ & $\begin{array}{l}714.39 \\
(2.36)\end{array}$ & $\begin{array}{l}938.17 \\
(2.88)\end{array}$ & $\begin{array}{l}740.90 \\
(2.43)\end{array}$ \\
\hline 4. & Manure and fertilizer & $\begin{array}{c}2109.23 \\
(7.01)\end{array}$ & $\begin{array}{c}2198.03 \\
(7.27)\end{array}$ & $\begin{array}{c}2311.82 \\
(7.10)\end{array}$ & $\begin{array}{c}2165.99 \\
(7.11)\end{array}$ \\
\hline 5. & Irrigation & $\begin{array}{l}4620.06 \\
(15.35)\end{array}$ & $\begin{array}{c}4626.16 \\
(15.31)\end{array}$ & $\begin{array}{c}5145.16 \\
(15.80)\end{array}$ & $\begin{array}{c}4687.30 \\
(15.39)\end{array}$ \\
\hline 6. & Plant Protection & $\begin{array}{l}140.38 \\
(0.47)\end{array}$ & $\begin{array}{l}218.69 \\
(0.72)\end{array}$ & $\begin{array}{l}521.5 \\
(1.60)\end{array}$ & $\begin{array}{l}215.52 \\
(0.71)\end{array}$ \\
\hline 7. & Total working capital & $\begin{array}{c}19434.64 \\
(64.57)\end{array}$ & $\begin{array}{c}19479.68 \\
(64.45)\end{array}$ & $\begin{array}{c}21470.39 \\
(65.80)\end{array}$ & $\begin{array}{c}19702.96 \\
(64.71)\end{array}$ \\
\hline 8. & Interest on working capital & $\begin{array}{l}971.73 \\
(3.23)\end{array}$ & $\begin{array}{l}973.98 \\
(3.22)\end{array}$ & $\begin{array}{c}1073.51 \\
(3.30)\end{array}$ & $\begin{array}{l}985.14 \\
(3.24)\end{array}$ \\
\hline 9. & Rental value of land & $\begin{array}{l}6500.00 \\
(21.60)\end{array}$ & $\begin{array}{l}6500.00 \\
(21.51)\end{array}$ & $\begin{array}{c}6500.00 \\
(19.97)\end{array}$ & $\begin{array}{l}6500.00 \\
(21.35)\end{array}$ \\
\hline 10. & Interest on fixed capital & $\begin{array}{l}456.71 \\
(1.52)\end{array}$ & $\begin{array}{l}522.19 \\
(1.73)\end{array}$ & $\begin{array}{l}552.41 \\
(1.70)\end{array}$ & $\begin{array}{l}491.91 \\
(1.62)\end{array}$ \\
\hline 11. & Sub total & $\begin{array}{c}27363.08 \\
(90.91)\end{array}$ & $\begin{array}{c}27475.85 \\
(90.91)\end{array}$ & $\begin{array}{c}29596.31 \\
(90.91)\end{array}$ & $\begin{array}{c}27680.04 \\
(90.91)\end{array}$ \\
\hline 12. & $\begin{array}{l}\text { Managerial Cost @10\% of } \\
\text { sub-total }\end{array}$ & $\begin{array}{c}2736.30 \\
(9.09)\end{array}$ & $\begin{array}{c}2747.58 \\
(9.09)\end{array}$ & $\begin{array}{c}2959.63 \\
(9.09)\end{array}$ & $\begin{array}{l}2768.00 \\
(9.09)\end{array}$ \\
\hline & Grand total & $\begin{array}{c}30099.38 \\
(100)\end{array}$ & $\begin{array}{c}30223.43 \\
(100)\end{array}$ & $\begin{array}{c}32555.94 \\
(100)\end{array}$ & $\begin{array}{c}\text { 30448.01 } \\
(100)\end{array}$ \\
\hline
\end{tabular}

(Figure in parentheses indicate the percentage to total) 
Table.2 Measures of per hectare cost and profit of Mustard (Rs.)

\begin{tabular}{|c|c|c|c|c|c|}
\hline \multirow{2}{*}{$\begin{array}{l}\text { S. } \\
\text { No. }\end{array}$} & \multirow{2}{*}{ Particulars } & \multicolumn{3}{|c|}{ Size group of farms } & \multirow[b]{2}{*}{ Overall average } \\
\hline & & Marginal & Small & Medium & \\
\hline 1. & Cost A1/A2 & 12276.99 & 15775.16 & 18807.35 & 14333.06 \\
\hline 2. & Cost B1 & 12733.70 & 16297.35 & 19359.76 & 14824.97 \\
\hline 3. & Cost B2 & 19233.70 & 22797.35 & 25859.76 & 21324.97 \\
\hline 4. & Cost C1 & 20863.08 & 20975.85 & 23096.31 & 21180.01 \\
\hline 5. & Cost C2 & 27363.08 & 27475.85 & 29596.31 & 27680.01 \\
\hline 6. & Cost C3 & 30099.38 & 30223.43 & 32555.94 & 30448.01 \\
\hline 7. & Yield q/ha. & 13.27 & 13.19 & 13.13 & 13.22 \\
\hline 8. & Grass Income & 44173.71 & 43861.68 & 43626.88 & 43994.73 \\
\hline 9. & Net return over cost $\mathrm{C} 3$ & 14074.33 & 13637.95 & 13501.04 & 13847.75 \\
\hline 10. & Family Labour Income & 24940.01 & 21064.33 & 17767.12 & 22669.76 \\
\hline 11. & Farm investment income & 25749.01 & 23903.34 & 23513.08 & 24814.09 \\
\hline 12. & Farm Business income & 31896.72 & 28086.52 & 24819.53 & 29661.67 \\
\hline 13. & Cost of production (q/ha.) & & & & \\
\hline & On Cost C3 basis & 2268.22 & 2291.38 & 2479.50 & 2302.65 \\
\hline 14. & Input-Output ratio & & & & \\
\hline a. & On the basis of cost A1 & $1: 3.59$ & $1: 2.78$ & $1: 2.31$ & $1: 3.06$ \\
\hline b. & On the basis of cost $\mathrm{B} 1$ & $1: 3.46$ & $1: 2.69$ & $1: 2.25$ & $1: 2.96$ \\
\hline c. & On the basis of cost $\mathrm{B} 2$ & $1: 2.96$ & $1: 1.92$ & $1: 1.68$ & $1: 2.06$ \\
\hline d. & On the basis of cost $\mathrm{C} 1$ & $1: 2.11$ & $1: 2.09$ & $1: 1.88$ & $1: 2.07$ \\
\hline e. & On the basis of cost $\mathrm{C} 2$ & $1: 1.61$ & $1: 1.59$ & $1: 1.47$ & $1: 1.58$ \\
\hline f. & On the basis of cost $\mathrm{C3}$ & $1: 1.46$ & $1: 1.45$ & $1: 1.34$ & $1: 1.44$ \\
\hline
\end{tabular}

Table.3 Production Elasticity of Mustard group on different size group of farmer

\begin{tabular}{|c|c|c|c|c|c|c|}
\hline $\begin{array}{c}\text { Size group of } \\
\text { sample farms } \\
\text { (hectares) }\end{array}$ & \multicolumn{4}{|c|}{ Production elasticity } & $\begin{array}{c}\text { Sum of elasticties } \\
\text { return to scale }\end{array}$ & $\mathbf{R}^{2}$ \\
\cline { 2 - 5 } & $\mathbf{X}_{\mathbf{1}}$ & $\mathbf{X}_{\mathbf{2}}$ & $\mathbf{X}_{\mathbf{3}}$ & $\mathbf{X 4}$ & \\
\hline $\begin{array}{c}\text { Marginal } \\
\text { Farmer } \\
\text { (Below 1 ha.) }\end{array}$ & $\begin{array}{c}0.284602^{*} \\
(0.119936)\end{array}$ & $\begin{array}{c}0.396436 * * \\
(0.040107)\end{array}$ & $\begin{array}{c}0.063844 \\
(0.113292)\end{array}$ & $\begin{array}{c}0.010769 \\
(0.019126)\end{array}$ & 0.75565 & $\begin{array}{c}0.9019 \\
5\end{array}$ \\
\hline $\begin{array}{c}\text { Small Farmer } \\
(1-2 \text { ha. })\end{array}$ & $\begin{array}{c}0.327195 \\
(0.167946)\end{array}$ & $\begin{array}{c}0.358847 * * \\
(0.064015)\end{array}$ & $\begin{array}{c}0.077121 \\
(0.180925)\end{array}$ & $\begin{array}{c}0.018534 \\
(0.027998)\end{array}$ & 0.781697 & $\begin{array}{c}0.9506 \\
5\end{array}$ \\
\hline $\begin{array}{c}\text { Medium } \\
\text { Farmer } \\
(2-4 \text { ha. })\end{array}$ & $\begin{array}{c}0.216324 \\
(0.490842)\end{array}$ & $\begin{array}{c}0.471182 \\
(0.302499)\end{array}$ & $\begin{array}{c}0.134918 \\
(0.314487)\end{array}$ & $\begin{array}{c}0.045786 \\
(0.056436)\end{array}$ & 0.868209 & $\begin{array}{c}0.9601 \\
5\end{array}$ \\
\hline
\end{tabular}

(Figures in parentheses indicate standard error of respective variables)

(* Statistically significant at 5 percent probability level)

(** Statistically significant at 1 percent probability level)

$\mathrm{X}_{1}, \mathrm{X}_{2}, \mathrm{X}_{3}, \& \mathrm{X}_{4}$, Stand for cost of seed, manure and fertilizers, irrigation and human labour.

Table.4 Marginal Value Productivity (MVP) of included factors in

Production process of Mustard crop

\begin{tabular}{|c|c|c|c|c|}
\hline \multirow{2}{*}{ Size group of farms } & \multicolumn{4}{|c|}{ Marginal value productivity of input / factors } \\
\cline { 2 - 5 } & $\mathbf{X}_{\mathbf{1}}$ & $\mathbf{X}_{\mathbf{2}}$ & $\mathbf{X}_{\mathbf{3}}$ & $\mathbf{X}_{\mathbf{4}}$ \\
\hline Marginal & 17.12565 & 8.879566 & 0.590894 & 0.049172 \\
\hline Small & 18.49679 & 7.115571 & 0.717253 & 0.098438 \\
\hline Medium & 9.988288 & 8.973719 & 1.116188 & 0.226597 \\
\hline
\end{tabular}

$\mathrm{X}_{1}, \mathrm{X}_{2}, \mathrm{X}_{3} \& \mathrm{X}_{4}$ stands for cost of seed, manure and fertilizer, irrigation charges and human labour, respectively. 
Coefficient of multiple determination $\left(\mathrm{R}^{2}\right)$ was used to express the variation of output by included factors in the production process. The statistically significant variables were seed at 5\% level (on marginal farms), manure $\&$ fertilizers (on marginal and small farms), at $1 \%$ level of probability in mustard crop while rest of the factors of production were found statistically non-significant on all categories of farms.

The marginal value productivity (MVP) of two input factors i.e. seed and manure and fertilizer were found more than unity in case of each size group of farms which revealed that there is further scope of investment on these factors to obtain optimum production from mustard in the study area. MVP of rest of two independent input factors i.e. irrigation charges and human labour were less than one, it means these two factor were excessively used than the optimum level.

On overall average, cost of cultivation per hectare of mustard came to Rs 30448.01. The net income, family labour income, farm investment income, and farm business income were found Rs. 13847.75 , Rs 22669.76, Rs 24814.09 and Rs. 29661.67, respectively from mustard crop. It is concluded from the results that various income measures were found in negative relation with size of holding. Due to some unrecorded reasons cost per hectare increased with holding size but sample farmers of all three categories could receive the equal yield. Which reversed the relationship of costs and income with size of holdings.

\section{References}

Ajit, Verma, Savita, Gupta, Singh, I. J. Singh, S. P. Avinash Kumar (2015). "Study the cost of cultivation and net income of mustard in different farm size groups on the fields." Banaras Hindu University - CAB Abstracts Plant Archives; 2015. 15(2):841-842. 3 ref.

Ashok Jaulkar Deopuria, O. P. Kushwaha, H. S. (1995). "Economic analysis of mustard seed cultivation in Gwalior district of Madhya Pradesh." Banaras Hindu University - CAB Abstracts Bhartiya Krishi Anusandhan Patrika; 1995. 10(3):156-158.

Kumar, M. S. Rajashekharappa, M. T. Pandey, L. M. Prem Narayan (2005). "Efficiency in Indian edible oilseed sector: analysis and implications." Banaras Hindu University - CAB Abstracts Agricultural Economics Research Review; 2005. 18(2):153-166.

Rashid, M. A. Anwar, M. M. (2004). "Profitability and resource use efficiency of mustard crop in selected areas of Bangladesh." Banaras Hindu University - $C A B$ Abstracts Economic Affairs (Calcutta); 2004. 49(2):87-93. $7 \mathrm{ref}$.

\section{How to cite this article:}

Praveen Kumar Sahu, Gyan Prakash Singh and Rajeev Singh. 2017. A Study on work out costs and returns and examine resource use efficiency in Mustard production on sample farms. Int.J.Curr.Microbiol.App.Sci. 6(8): 3194-3202. doi: https://doi.org/10.20546/ijcmas.2017.608.381 